\title{
The EfFect of Principal Leadership Style, Work Motivation, ANd Professional Competence of Primary School Teacher Performance in Kendari City
}

\author{
Ridwan Yusuf Deluma ${ }^{1)}$, Zulela MS $^{2)}$, Moch. Asmawi ${ }^{3)}$ \\ ${ }^{1)}$ University of Southeast Sulawesi, Palu, Indonesia \\ E-mail: ridwan@mahasiswa.unj.ac.id \\ ${ }^{2)}$ Universitas Negeri Jakarta, Jakarta, Indonesia \\ E-mail: zulela@unj.ac.id \\ ${ }^{3)}$ Universitas Negeri Jakarta, Jakarta, Indonesia \\ E-mail: moch.asmawi@unj.ac.id
}

\begin{abstract}
This study aimed to determine the effect of the principal's leadership style, motivation, and professional competence on the performance of an elementary school teacher in the town of Kendari. The design of this research was path analysis. The study samples were 241 primary school teachers and they were taken by using a simple random sampling technique. Data were collected by questionnaire and analyzed statistically using path analysis with the program Linear Structural Relations (LISREL). The professional competence was equal py $23=0.389, \mathrm{t}=4.751$, table $=1,97$ means $\mathrm{t}>\mathrm{t}$ table, then $\mathrm{H} 0$ was rejected and $\mathrm{H} 1$ was accepted The results showed that: (1) there was a positive direct influence between headmaster leadership style to the performance of primary school teachers in the city of Kendari, (2) there was a direct positive influence between work motivation on the performance of primary school teachers in the city Kendari. The conclusion of this research are: (1) There is a positive direct influence on the performance of the leadership style of primary school teachers in Kendari; (2) There is a positive direct influence on the performance of work motivation of primary school teachers in Kendari; (3) There is a positive direct influence on the performance of the professional competence of primary school teachers in Kendari; (4) There is a positive direct influence on the performance of motivational leadership style work in Kendari; (5) There is a positive direct influence leadership style to the professional competence of teachers of primary schools in Kendari.
\end{abstract}

Keywords: Leadership Style; Work Motivation; Professional Competence; Teacher Performance

\section{INTRODUCTION}

Education is a strategic vehicle used to improve the quality of human resources which is a determinant of development. Education is a conscious effort to prepare students through guidance, teaching, and/or training activities for their future roles. The quality of education and graduates are often seen depend on the teacher's role in managing the teaching components used in the learning process, which is the responsibility of the school.

Elementary school is an organization that requires integrated management, both by the teacher as the implementer of learning activities in the classroom and by the principal as the activity controller in the school. Good coordination by the principal builds up the achievement of school goals, as well as the goals of the individuals in the school environment. Besides, the teacher's responsibility in carrying out learning activities and creating a conducive situation is a prerequisite for the success of school goals. Thus, primary school teachers play important roles, both in managing learning activities and in managing administration that can support the success of achieving school goals.

Recognizing the heavy roles and duties carried out by the teacher, the quality of teacher performance is needed. Teacher performance is the teacher's ability to act following its intended purposes, which includes aspects of planning a learning program, implementation of the learning process, 
optimal class creation and maintenance, optimal control of learning conditions, and assessment of learning outcomes.

Due to this matter, the ministries of education and culture have made various efforts to improve the quality of national education such as the development of national and local curriculum, teacher competency improvement through training and qualification programs and teacher certification programs, and the procurement of textbooks from learning support tools, procurement and repair of facilities and educational infrastructure, improvement of school management, and other supporters. Relative to the ministry of education and culture has made various efforts to improve the quality of national education such as curriculum development, national and local, improving the competence of teachers through training and qualification programs and teacher certification programs and the procurement of textbooks of support tools lessons, provision and improvement of educational facilities, improvement of school management, and other supporters.

The implementation of education in schools will go well if it is supported by high teacher performance, even though it is realized that many components are related in the learning process, which each component supports each other to achieve educational goals both at the education unit level and at the national level.

The performance of teachers in schools has an important role in achieving the goals of the school. Performance is a form of behavior a person or organization with achievement orientation. A form of behavior in question is the activities of teachers in the learning process, that is how a teacher lesson plan, implement learning activities, and assess learning outcomes (Rusman, 2011: 30). Meanwhile, according to Wahab \& Umiarso (2011: 56), the performance of teachers is the ability shown by teachers in carrying out their duties. Thus the performance of the teacher is the teacher's perception of the performance of teachers about the quality of work, responsibility, honesty, cooperation, and initiative. Performance is said to be good and satisfactory if the objectives are achieved following established standards.

Basically, the teacher's performance is influenced by factors of the teachers themselves such as personality and dedication, professional development, teaching skills, community relations, intelligence, skill and prowess, abilities and interests, experience, satisfaction, talent, motivation, health, and ideals ideal and purpose in work. While external factors are predicted to affect the performance of a teacher among which, the principal's leadership style, family environment, work environment, facilities, and infrastructure (Wahab \& Umiarso, 2011: 23).

The school principal is one of the most important factors deciding reciprocation of the education process in schools. The leadership style is consistently applied behavioral patterns leader through other people is through behavior that is shown when the leader affects others, as perceived by others. Style is not about how the opinion leaders or principals about their behavior in the lead but how the perception of others, especially subordinates or teacher about leadership behavior (Darma and Usman, 2009: 67).
School leadership to determine the quality, without the good leadership quality improvement process cannot be carried out and realized. Primacy effect (influence) the principal's leadership is not merely a form of instruction, but rather a motivation or trigger (trigger) that can give inspiration to teachers and employees so that the initiative and creativity to develop optimally to improve its performance. The reality in the field of school leadership still shows its performance is not optimal, it indicated among others still lacks principals to conduct teacher supervision and the level of satisfaction of the principal's leadership is still low (Carudin, 2011: 47).

Teachers are the spearhead that is on the forefront that directly deals with students through learning activities in the classroom or outside the classroom. Teachers are also required to carry out clear throughout professional functions effectively and efficiently. Neither of the interests of national education and functional tasks of teachers, all of them demanding that education and teaching carried out professionally means implemented in earnest and supported by teachers who have a good performance. Teachers are required to have performance that can provide and realize the hopes and wishes of all parties, especially the general public who have placed their trust in schools and teachers in fostering students.

In general, good quality of education became the benchmark for the success of the performance of the teachers. Teachers in principle have a high enough potential to be creative to improve their performance. But the potential of teachers to be creative to improve its performance does not always develop naturally and smoothly due to the influence of various factors, both personal teacher who appears in itself and that there is a private outside teacher. A teacher's performance can be influenced by personal relationships, school leadership, motivation, ability to work, skills, working facilities, work ethic, and technology.

School as an organization, usually the teacher's performance is determined by the principal's leadership style (Carudin, 2011: 48). But the potential of teachers to be creative to improve its performance does not always develop naturally and smoothly due to the influence of various factors, both personal teacher who appears in itself and that there is a private outside teacher. A teacher's performance can be influenced by personal relationships, school leadership, motivation, ability to work, skills, working facilities, work ethic, and technology. School as an organization, usually the teacher's performance is determined by the principal's leadership style (Carudin, 2011: 48 ). But the potential of teachers to be creative to improve its performance does not always develop naturally and smoothly due to the influence of various factors, both personal teacher who appears in itself and that there is a private outside teacher.

A teacher's performance can be influenced by personal relationships, school leadership, motivation, ability to work, skills, working facilities, work ethic, and technology. School as an organization, usually the teacher's performance is 
determined by the principal's leadership style (Carudin, 2011: 48). School leadership, motivation, ability to work, skills, working facilities, work ethic, and technology. School as an organization, usually the teacher's performance is determined by the principal's leadership style (Carudin, 2011: 48). school leadership, motivation, ability to work, skills, working facilities, work ethic, and technology. School as an organization, usually the teacher's performance is determined by the principal's leadership style (Carudin, 2011: 48).

Further motivation is the psychological factor that is nonintellectual. The typical role is in terms of growing passion, happiness and eagerness to learn and teach. Students and teachers who have strong motivation will have lots of energy to do learning activities. Hasibuan (2009: 50) said that motivation is the driving force that creates the administration excitement a person's work, so that they would cooperate, to work effectively, and Integrate with all its resources to achieve satisfaction. Meanwhile, according to Widodo (2011: 32) that motivation is the central management, for explaining how people behave and how they do work in the organization. Motivation comes from within (intrinsic) and none from outside (extrinsic). The leader must have a high performing team, to motivate their members to be able to work well, so that organizational goals achieved.

Work motivation can be defined as conditions that affect evoke, directing, and maintaining behavior associated with the work environment. The working environment in question is a school, a school as an organization in which some people work together to achieve the goal. To achieve these objectives the role of human resources involved in it is very important to be moved in the manner intended by the organization. Thus the motivation will be a determining factor for the behavior of people working or we say the behavior is a reflection of the simplest of motivation. As the result of one act of motivation is to achieve the performance of the organization as a whole.

In addition to the style of leadership and motivation affects the performance of teachers, professional competence as well as agents of learning at primary and secondary levels of education and early childhood education greatly affects the performance of teachers. Susilo et al. (2011: 67) stated that professional competence is the ability of mastering learning materials widely and deeply. While Rusman (2011: 43) said that the professional competence of teachers are those who specifically work based on the expert teacher with a deep understanding of the foundations of education, and academically own theories of education and have the skills to be able to implement educational theory such. The professional competence of teachers is closely linked to the performance of teachers in the learning process.

Due to this matter, the government's efforts to improve the performance of primary school teachers are still low, especially in the city of Kendari, which is one important aspect that must be considered. How do we ensure that teachers in primary schools have absolute high performance must be considered, both by teachers and principals. Teachers must have a high motivation to work and have a good professional competence, as well as the principal leaders in the school, must try to use a leadership style that can encourage subordinates to optimize their performance. It is important for improving the performance of the primary school teacher in the town of Kendari.

Based on the above, it is necessary to conduct a study on the Influence of the principal's leadership style, motivation, and professional competence on the performance of an elementary school teacher in the town of Kendari. The formulation of the problems in this study can be seen in the followings:

1. Did leadership style directly affect the performance of primary school teachers in the city of Kendari?

2. Did the motivation to work directly affect the performance of primary school teachers in the city of Kendari?

3. Did professional competence directly affect the performance of primary school teachers in the city of Kendari?

4. Did leadership style directly affect the work motivation of primary school teachers in the city of Kendari?

5. Did leadership style directly influence the professional competence of primary school teachers in the city of Kendari?

\section{METHODOLOGY}

This study used a survey method with the approach path analysis (path analysis) to test the effect of independent variables (the principal's leadership style, motivation, and professional competence) on the dependent variable (performance of teachers). The data in this study were taken directly without conducting experiments in advance. The study involved 241 primary school teachers in the city of Kendari as a sample. Sampling was done by random sampling technique for the research sample. Then questionnaires of principal leadership style, motivation, professional competence, and performance of teachers that were validated were given to the samples to be answered. Data were analyzed statistically using path analysis (path analysis).

\section{RESULTS AND DISCUSSION}

Based on the results of hypothesis testing by using path analysis, the result can be seen in the followings:

\section{A. The principal's leadership style directly impacts positively on the performance of primary school teachers in Kendari}

Based on the results of path coefficient calculation principal's leadership style variables on the performance of primary school teachers was at $\rho y 1=0.369, \mathrm{t}=5.704$, table $=1,97$ means $\mathrm{t}>\mathrm{t}$ table, then $\mathrm{H} 0$ was rejected and $\mathrm{H} 1$ was accepted, it means a significant $\rho y 1$ path coefficients. Thus there was a direct positive influence on school leadership style to the performance of an elementary school teacher in the town of Kendari. 
This means that the higher the leadership style of the principal, the higher the teacher's performance. This can be used as an indication that the principal's leadership style can be used as a predictor of the performance of elementary school teachers in the city of Kendari City, or in other words that the leadership style of the principal functions as a determinant of the performance of primary school teachers in Kendari City. The effective contribution of the principal's leadership style variable to the performance of primary school teachers in Kendari city was 0.369 . In other words, the principal's leadership style contributed to the performance of elementary school teachers in Kendari City.

The leadership style is one factor that can positively influence the performance of teachers. A good leadership style, of course, will inspire teachers to work well. Principals who have high leadership style will be respected by the teachers because it could be an example of teachers in work. Conversely, if the principal has a low leadership style, then the teachers tend to underestimate the principal. As a result, the teacher will of course be lazy to demonstrate its performance to the maximum.

The results of this study were supported by the findings of research conducted by Yawan (2012: 184-194) that the principal's leadership style had a significant influence on the performance of primary school teachers. The higher the style of leadership of the principal, the higher the performance of a primary teacher's ability to manage the class. The leadership style is high on the head of the school is one good way to improve the performance of teachers.

The leadership style is an attitude that is chosen by the individual leader' in his leadership duties. The force used by a leader different from one another depending on the circumstances of his leadership. Daryanto (2011: 39) stated that the style of leadership that uses violence affects work productivity improvement only at its beginnings only, so productivity cannot be guaranteed. Violence can grow the compulsion to be able to lower labor productivity.

In the context of this study, the principal is a leader in school if leading the use of force will only reduce the performance of teachers. Teachers will find work under pressure and threats. Thus, the teachers will tend to avoid the principal. This leads to communication between teachers and principals will be uninterrupted or likely to drop out.

Conversely, if the principal implementing a more democratic leadership style will grow a sense of familiarity between leaders and subordinates. Indeed, the leader must be firm, but that does not mean authoritarian or even use violence in the lead. Firmly means leaders can be consistent against any decision taken and run it as well as possible. Principals who have a democratic style will tend to be easier to communicate with teachers. Teachers will not feel scared or under pressure when the principal asked them to discuss. With good communication, principals and teachers will work together well and the teacher will be able to show productivity or maximum performance because it gets a good referral from the principal.
B. Work motivation positive direct influence on the performance of primary school teachers in Kendari

Based on the results of path coefficient calculation motivation to work on the performance of primary school teachers was at $\rho y 2=0.314, \mathrm{t}=5.377$, table $=1,97$ means $\mathrm{t}>$ $\mathrm{t}$ table, then $\mathrm{H} 0$ was rejected and $\mathrm{H} 1$ was accepted, it means a significant $\rho y 2$ path coefficients. Thus, there was a positive direct influence on the performance of work motivation primary school teacher in Kendari City.

This means that the higher work motivation, the higher the performance of teachers. It can be used as an indication that motivation can be used as a predictor of the performance of an elementary school teacher in the city of Kendari, or in other words that motivation of teachers to work determinant of the performance of an elementary school teacher in the town of Kendari. Effective contribution to the performance of work motivation of primary school teachers in the city of Kendari at 0.314. In other words, work motivation to contribute to the performance of an elementary school teacher in the town of Kendari.

Motivation is the drive to do something. People who are motivated to do something usually do something better than the person who did it had to. In terms of performance, the motivation could be the trigger zeal in improving the performance itself. Motivated people usually want to show that they could be and better than others. People who are motivated are usually afraid of failure. This is what makes people motivated is always the spirit of the show performance.

This is consistent with the results of research by Zetriuslita and Wahyuni (2013: 6) about the relationship between work motivation and performance of teachers, that there was a positive and significant effect on the motivation to work on the performance of primary school teachers. The results of the same study found by Manik and Bustomi (2011: 97-107) that there was a positive correlation between work motivation and the performance of teachers. This means the higher the work motivation of teachers, the higher the teacher's performance. This study revealed that teachers who have high motivation to work tend to do things better than the teachers who have low motivation. Teachers who have a high motivation to work has a peak performance.

According to Herzberg's theory, the factors that drive employee motivation aspect is the success, recognition, nature of work is the responsibility of a person, an opportunity for progress and growth. While the factors that stand out are hygiene, company policies, supervision, working conditions, wages and salaries, relationships with colleagues, personal life, relationships with subordinates, status, and security. People who are motivated in their work, of course, want to achieve successful performance professional duties and achievements gained recognition from their peers. Besides, people who are motivated to work usually have a high responsibility for their performance. This has spurred the teachers are motivated in their work to have a very high performance in the task of their profession as a teacher. 
Teachers who avoid failure usually want to get recognition from his friend. So that they are motivated to do the job at hand. To receive recognition, of course, they must show brilliant performance in their duties.

\section{Professional competence positive direct influence on the performance of primary school teachers in Kendari}

Based on the results of professional competence path coefficient calculation on the performance of primary school teachers was at $\rho y 3=0.338, \mathrm{t}=3.547$, table $=1,97$ means $\mathrm{t}>$ $\mathrm{t}$ table, then $\mathrm{H} 0$ was rejected and $\mathrm{H} 1$ was accepted, it means a significant $\rho y 3$ path coefficients. Thus there was a positive direct influence on the performance of the professional competence of primary school teachers in Kendari.

This means that the higher the professional competence of teachers, the higher the performance of teachers. It can be used as an indication that the professional competence can be used as a predictor of the performance of an elementary school teacher in the city of Kendari, or in other words that the professional competence of teachers to work determinant of the performance of an elementary school teacher in the town of Kendari. Effective contribution of professional competence variables on the performance of primary school teachers in the city of Kendari at 0.338 . In other words, professional competence has contributed positively to the performance of an elementary school teacher in the town of Kendari.

Professional competence is the ability to give someone in carrying out their duties professionally. In the context of this research, professional competence is the ability of a teacher to perform his duties as a teacher in a professional manner. Professional competence is an integral part of the four main competencies that must be owned by a teacher, pedagogical, personality, social, and professional. The fourth competence is integrated into teacher performance when carrying out their profession. Teachers who have the competence fourth will certainly have a better performance than that do not have the competencies. Teachers who have the competence fourth course would have no difficulty in addressing its performance because they are more confident.

The results are consistent with the findings of research conducted by Widiastuti et al. (2013: 72) that there was a positive relationship between teachers' professional competence and performance. This study found that the higher the competence of teachers, the higher the performance of teachers. Among the three independent variables studied, Teacher professional competence variables contributed most among the other independent variable that is equal to $13 \%$.

Professional competence can improve the performance of a teacher. Teacher performance shown is based on real things that can teachers do in their duties as a teacher. If we refer to the professional competence of the teacher's reach that good professional competence will be able to show tangible things they can do in their duties as a teacher. This means that the teacher's performance will be very good if the high professional competence of teachers.
D. The principal's leadership style directly positive effect on the work motivation of primary school teachers in Kendari

Based on the calculation coefficient principal's leadership style track towards the achievement motivation was for $\rho 21$ $=0.327, \mathrm{t}=2.889$, table $=1,97$ means $\mathrm{t}>\mathrm{t}$ table, then $\mathrm{H} 0$ was rejected and $\mathrm{H} 1$ was accepted, it means a significant py21 path coefficients. Thus there was a direct positive influence on the principal's leadership style to the work motivation primary school teacher in the town of Kendari.

This means that the higher the principal's leadership style, the higher the teacher work motivation. It can be used as an indication that the principal's leadership style can be used as predictors of employee motivation primary school teacher in the city of Kendari, or in other words that the principal function of leadership style determinants of work motivation primary school teacher in the town of Kendari. The effective contribution of the principal's leadership style variables on the performance of primary school teachers in the city of Kendari at 0.327 . In other words, the principal's leadership style contributed to the work motivation of primary school teacher in the town of Kendari.

The results are consistent with research conducted by Juniarti (2010: 115) that principal leadership style had a significant influence on the work motivation of teachers. The higher the principal's leadership style, employee motivation, the higher the teacher. The leadership style is high on the head of the school is one great way to increase the motivation of teachers in primary schools. The same study also found Lestari (2014: 147) that principal leadership style has a significant influence on the work motivation of teachers.

The results of another study conducted by Supardi (2016: 11-30), found that the principal's leadership style had a significant influence on the work motivation of teachers. The higher the principal's leadership style, employee motivation, the higher the teacher. The leadership style is high on the head of the school is one great way to increase the motivation of teachers' work. Effective school leadership will be reflected in its ability to motivate teachers to complete tasks and work, do a good harmonious relationship in the internal school and out of school, be able to apply the principles of leadership following the maturity level of the teacher and managed to realize the objectives of the school.

This suggests that in pursuing that teachers have high performance, then efforts should be made by teachers and principals. As a teacher in elementary school, teachers must have high motivation. Teachers in primary schools need to understand its function as an educator, lecturer, and mentor for students so that teachers be responsive, aware of the situation and learning conditions, and understand everything that is desired for students. In addition to understanding its function, teachers need to increase the motivation of the work that has the right attitude towards the learning environment, skills, and techniques in teaching. Thus in the face of circumstances that limited school will be a means of supporting the learning process. 
E. The principal's leadership style directly impacts positively on the professional competence of primary school teachers in Kendari

Based on the results of path coefficient calculation principal leadership style to the professional competence was equal py $23=0.389, \mathrm{t}=4.751$, table $=1,97$ means $\mathrm{t}>\mathrm{t}$ table, then $\mathrm{H} 0$ was rejected and $\mathrm{H} 1$ was accepted, it means a significant py31 path coefficients. Thus there is a direct positive influence on school leadership style to the professional competence of teachers of primary schools in the town of Kendari.

This means that the higher the principal's leadership style, the higher the professional competence of teachers. It can be used as an indication that the principal's leadership style can be used as a predictor of competence professional elementary school teacher in the city of Kendari, or in other words that the leadership style of the principal function of the determinants of professional competence of teachers of primary schools in the town of Kendari. The effective contribution of the principal's leadership style variable to the professional competence of primary school teachers in the city of Kendari at 0.389 . In other words, the principal's leadership style contributes to the professional competence of teachers of primary schools in the town of Kendari.

The results are consistent with research conducted by Banani (2017: 67-76) that the principal's leadership style had a significant influence on the professional competence of teachers. The higher the style of leadership of the principal, the higher the teacher's professional competence. The leadership style is high on the head of the school is one great way to improve the professional competence of teachers. Professional competence of teachers is a basic ability in performing the duties of a teacher with high ability, both as a teacher, counselor, or administrator implemented responsibly and feasibly.

Principal creative and productive will conduct educational innovation to improve the professional competence of teachers. Because the behavior of school leadership would affect teachers to develop competencies which are important factors in carrying out their duties and functions. There is a significant difference in the professional competence of teachers who influenced the style of school leadership are good and which are not. School leadership (leader) provides evaluation, feedback to the teacher, the professional competence of teachers will be increased. Noting the above statement, then the principal's leadership style is an important factor in the development of professional competence to improve the performance of teachers in schools.

\section{CONCLUSIONS}

Based on data analysis and discussion, we conclude several things: (1) There is a positive direct influence on the performance of the leadership style of primary school teachers in Kendari; (2) There is a positive direct influence on the performance of work motivation of primary school teachers in Kendari; (3) There is a positive direct influence on the performance of the professional competence of primary school teachers in Kendari; (4) There is a positive direct influence on the performance of motivational leadership style work in Kendari; (5) There is a positive direct influence leadership style to the professional competence of teachers of primary schools in Kendari.

Based on the research results, and paying attention to the limitations of the study, some suggestions need to be recommended as follows: (1) for the government, particularly the Department of Education, Youth and Sports Kendari, made as input and review of the policymakers, especially about increase the principal's leadership style and work motivation of teachers in improving teacher performance to improve the quality of education in the city of Kendari; (2) for principals and teachers, to be used as input and internal evaluation to continuously improve employee motivation to improve the professional competence and performance of primary school teachers in the city of Kendari; (3) for researchers, the expected results of this study can be used as a reference for further research.

\section{REFERENCES}

Banani, Muhamad Taufik. (2017). Pengaruh Kepemimpinan Kepala Sekolah Terhadap Kompetensi Guru dalam Mewujudkan Efektivitas Pembelajaran. Jurnal Pendidikan Universitas Garut, 11(1), 67-76.

Carudin. (2011). Pengaruh Kepemimpinan Kepala Sekolah Dan Iklim Kerja Sekolah Terhadap Kinerja Guru. Edisi Khusus, 2, 47-48.

Darma, Surya \& Usman, Husaini. (2009). Kepemimpinan Kepala Sekolah/Madrasah Yang Efektif. Jurnal Tenaga Kependidikan, 3(2), 67.

Daryanto. (2011). Kepala Sekolah Sebagai Pemimpin Pembelajaran. Yogyakarta: Penerbit Gava Media, 39.

Hasibuan, H. Malayu, S.P. (2009). Manajemen Sumber Daya Manusia. Jakarta: Penerbit Bumi Aksara, 50.

Juniarti, Anita. (2010). Pengaruh Gaya Kepemimpinan Kepala Sekolah Terhadap Motivasi Kerja Guru di MAN Malang II Batu. Tesis. Pascasarjana Universitas Negeri Malang, 115.

Lestari, Mixci Rina. (2014). Pengaruh Gaya Kepemimpinan Kepala Sekolah Terhadap Motivasi Kerja Guru. Tesis. Pascasarjana Universitas Jember, 147.

Manik, Ester dan Bustomi, Kamal. (2011). Pengaruh Kepemimpinan Kepala Sekolah, Budaya Organisasi dan Motivasi Kerja Terhadap Kinerja Guru Pada SMP Negeri 3 Rancaekek. Jurnal Ekonomi, Bisnis \& Enterpreneurship, 5(2), 97-107.

Rusman. (2011). Model-model Pembelajaran Mengembangkan Profesionalisme Guru. Bandung: PT Raja Grafindo Persada, 30.

Supardi. (2016). Pengaruh Gaya Kepemimpinan Kepala Sekolah Terhadap Motivasi Kerja Guru SDN Mangkujajar Kembangbahu Lamongan. Jurnal Ilmiah Pendidikan dan Pembelajaran Cendekia, 2(2), 11-30. 
Susilo, H., Chotimah, H., Joharmawan, R., Sari, Y.D., dan Sunarjo. (2011). Lesson Study Berbasis Sekolah, Guru Konservatif Menuju Guru Inovatif. Malang: Mayumedia Publishing, 67.

Wahab, Abd. \& Umiarso. (2011). Kepemimpinan Kependidikan dan Kecerdasan Spiritual. Yogyakarta: AR-Ruzz Media, 23-56.

Widiastuti, Komang wiwin sri, et al. (2013). Pengaruh Kompetensi Profesional dan Motivasi Kerja terhadap Kinerja Guru di smk triatmajaya Singaraja Tahun Ajaran 2012/2013. Singaraja: Universitas Pendidikan Ganesa, 72.
Widodo. (2011). Pengaruh Gaya Kepemimpinan, Budaya Organisasi, dan Motivasi Kerja Terhadap Kinerja Guru. Jurnal Pendidikan Penabur, 17(10), 32.

Yawan, Ruth. (2012). Pengaruh Motivasi Kerja Guru dan Gaya Kepemimpinan Kepsek Terhadap Kinerja Guru SD Biak Numfor Papua. Jurnal Pendidikan Matematika dan Sains, 4(2), 184-194.

Zetriuslita, Z., \& Wahyuni, R. (2013). Hubungan Motivasi Kerja dan Kesejahteraan Terhadap Kinerja Guru Matematika Sekolah Menengah Pertama di Kota Pekanbaru. Jurnal Pendidikan Matematika dan Sains, $\quad 1(1), \quad 1-7$. doi:http://dx.doi.org/10.21831/jpms.vlil.12471, h. 6 . 